The University of Akron

\title{
IdeaExchange@UAkron
}

Proceedings from the Document Academy

University of Akron Press Managed

December 2016

\section{Foundational Review on Information Seeking Behavior of Legislators}

Yousef T. Alfarhoud

University of North Texas, yalfarhoud@gmail.com

Please take a moment to share how this work helps you through this survey. Your feedback will be important as we plan further development of our repository.

Follow this and additional works at: https://ideaexchange.uakron.edu/docam

Part of the Library and Information Science Commons, and the Political Science Commons

\section{Recommended Citation}

Alfarhoud, Yousef T. (2016) "Foundational Review on Information Seeking Behavior of Legislators," Proceedings from the Document Academy: Vol. 3 : Iss. 2 , Article 11.

DOI: https://doi.org/10.35492/docam/3/2/11

Available at: https://ideaexchange.uakron.edu/docam/vol3/iss2/11

This Conference Proceeding is brought to you for free and open access by University of Akron Press Managed at IdeaExchange@UAkron, the institutional repository of The University of Akron in Akron, Ohio, USA. It has been accepted for inclusion in Proceedings from the Document Academy by an authorized administrator of

IdeaExchange@UAkron.For more information, please contact mjon@uakron.edu, uapress@uakron.edu. 


\section{Introduction}

As an information specialist working in the Kuwait National Assembly (KNA), I observed the information use by members of KNA and rapid adoption of technology, specifically social media, by members of KNA and Kuwaiti citizens. I have been applying an information seeking behavior lens and the insights of a participant observer to modeling the constellation of relations and consequences of this fundamentally new medium for bringing information to the point of use. The foundation for this research follows.

Information seeking behavior refers to strategies for locating information and has three elements: systems, information, and people. The study of individual information seeking behavior requires understanding of the psychological state of the user that may lead to insight into their expectations and make it possible to predict information seeking activity (Ocholla, 1999). Information behavior is defined as the "set of activities a person may engage in when identifying his or her own needs for information, searching for information, retrieving information in any way, and transferring and using that information" (Wilson, 1999, p. 249).

Information has a crucial impact on decision-making. The value of information is tied to the decisions that result from its use. Its value is related to those who use it and to when it is used. Information is significant if it helps to improve decision-making (Frankor \& Akussah, 2012). According to two studies, conducted by Marcella, Carcary, and Baxter (1999) and Osman and Agyei (2014), decision-making is a procedure that results in a formal judgment or choice being reached. For this to be possible, choices or options must be provided from which a selection can be made. The ability to evaluate or to choose from different options depends on the accessing of accurate, reliable, and comprehensive information. It is crucial that decision makers have access to information that is unbiased and reflects the entire range of available opinion. Furthermore, the transformation of information about these variables into knowledge is important to the effectiveness of the decision-making process.

It is commonly understood that legislators are the most influential decision makers in any society. They represent a broad range of interests, backgrounds, experiences, and networks. The legislators acquire information that is reflected in their work outcome. Legislators use various types of information to support their legislative work. The decision-making process largely depends on the quality of information they acquire.

Legislators have the privilege to suggest new laws and legislate proposals. Therefore, the quality of information provided may affect the quality of the legislative proposals they present. It is crucial to understand legislators' information seeking behavior to help identify the proper sources and types of information acquired by the legislators. This approach will help to identify the 
accurate and reliable information that will help decision-making process. Shailendra and Parkash (2007) conducted a study on the information needs of members of the Legislative Assembly (MLAs) of Delhi, India. They described the term "need" as an abstract term that refers to a lack of self-efficacy on one's part. It indicates a gap in one's current knowledge, which eventually makes the person unsatisfied. As stated by Orton, Marcella, and Baxter (2000), members of the United Kingdom parliament are expected to be knowledgeable about a wide variety of issues. Therefore, their information need is frequently unpredictable and they depend on those who provide them with information. The authors concluded by arguing that if we want to speed up the pace of development of our nation, we must provide current, speedy, relevant, and exhaustive information to the members of the parliament.

This study will identify the information behavior and needs of members of the Kuwait National Assembly. The State of Kuwait is an Arab State, independent and fully sovereign, situated in the northeast of the Arabian Peninsula in Western Asia. Islam is the religion of the State, and it is the main source of legislation. The official language of the State is Arabic. The System of Government in Kuwait is democratic. The Kuwaiti government consists of the executive, legislative, and judicial bodies. The legislative body, which is the Kuwait National Assembly (KNA), represents the Kuwaiti society with fifty elected parliament members.

\section{Information Seeking Behavior}

The history of research on information seeking goes back to Eliot's 1902 research on the usage of a library's collection in the pre-WWII era (Case, 2012; Wilson, 2000, 2006). After WWII, there was a noticeable increase in the amount of scientific research that had recently been published or was released after the war due to former restrictions. This led to the Royal Society Scientific Information Conference in 1948, and perhaps to the first published research on information use, J.D. Bernal's great contribution in the conference. Later, in 1958, there was a follow-up conference called the International Conference on Scientific Information. The two conferences can be considered as the starting point of the understanding how people used information in their work and the reasons and ways they used information in science and technology (Wilson, 2000, 2006). As the conferences agendas suggest, much of research studies have provided reports about the use of scientific and technical information (Folster, 1995).

In 1951, Information Retrieval (IR) was introduced to information science and contributed theories and models to the field. Advancements in information retrieval gave the scientists, scholars, and librarians the opportunity to develop many theoretical, empirical, and pragmatic concepts (Saracevic, 1999). The dilemma with IR systems is that in the past they were created and based on a 
system-centered approach (Bates, 1999). This dilemma has led many information scientists to be concerned with limitations on its ability to empower users, which led them to consider "Information Seeking" as a broader process rather than entertaining a more static notion about IR (Marchionini, 1997). Therefore, information seeking is another domain within the information science field.

Post-1960, there have been many studies on information seeking behavior by social scientists. These studies have focused on the type of information people use and the reason they use it. Folster (1995) reported that all research on information behavior is "primarily citation studies" (p. 84). In the last 20 years, the subject of information behavior has become a popular area of doctoral research in the field of library and information science (Wilson, 2000, 2006). Moreover, the establishment of theoretical and conceptual frameworks in the field also began, specifically starting with models of the information seeking process (Kuhlthau, 2004; Wilson, 1981, 1999, 2009). Finally, technology has played a major role in changing how people seek for and use information; it has also changed how scientists research the subject of information behavior (Wilson, 2006).

Bates (2010) stated that over the past 50-60 years, research on information behavior have been referred to interchangeably in three different terms: use studies; information seeking or information needs and uses; and information behavior. Information behavior seems to be the most dominant and widely used term these days (Wilson, 2009; Case, 2012). This may be explained as owing to its being a wider concept and a more comprehensive term encompassing "all kinds of research on people's interaction with information" (Bates, 2010, p. 2382). Information seeking can be defined as a "process in which humans purposefully engage in order to change their state of knowledge" (Marchionini, 1997, p. 5). Moreover, information behavior is defined as the "set of activities a person may engage in when identifying his or her own needs for information, searching for information, retrieving information in any way, and transferring and using that information" (Wilson, 1999, p. 249). Wilson (2000) stated there are many terms for information behavior, including information seeking behavior, information behavior, information searching behavior, and information use behavior. The four terms appear to overlap. The author defined information behavior as

the totality of human behavior in relation to sources and channels of information, including both active and passive information seeking, and information use. Thus, it includes face-to-face communication with others, as well as the passive reception of information as in, for example, watching TV advertisements, without any intention to act on the information given (p. 49) 


\section{Theories and Models of Information Seeking Behavior}

A theory's main goal is to help scientists understand the phenomena which are important to the concept being investigated (Rocco \& Hatcher, 2011). Camp (2001) defined theory as "a set of interrelated constructs, definitions, and propositions that present a rational view of phenomena by explaining or predicting relationships among those elements" (p. 8). Over the years, information science has developed several theories and models regarding information seeking behavior. Case (2012) mentioned nine known models in the information needs and behavior literature. Eight of the models are from the information science literature: Krikelas' (1983) model of information seeking behavior; Ellis' (1989, 1993 ) information seeking theory model; Kuhlthau's (1991) information search process; Bystrom and Jarvelin's (1995) model; Leckie's (1996) information seeking model; and two information seeking behavior models proposed by Wilson (1981, 1996). Other examples of information seeking theories include Chatman's insider-outsider effect theory; Belkin, Oddy, and Brook's anomalous states of knowledge; Bates' berrypicking model; Marchionini's information seeking model; and Dervin's sense-making theory, which is one of the most cited theories originating outside the information science field.

Osman and Agyei (2014) stated that theory provides the starting point for research. Research work should be based on some theoretical framework. Moreover, developing and using models may help to guide an understanding of the probable information needs of legislators. Marcella, Baxter, and Moore (2002) conducted a review of studies on the information needs related to the communication of parliamentary information; they concluded that many researchers have noticed the shortage of models and frameworks in the area of information seeking. The authors indicated that the problem might not be the lack of theory, but rather the lack of a road map guiding us to use or create a theory.

\section{Legislators' Information Seeking Behavior}

Scholars have conducted various studies to investigate the information seeking behavior of legislators. Many of the studies addressed in this review did not adopt or include theories or models in their design. However, two studies have used Wilson's (1996; 1999) model. First study by Osman and Agyei (2014) investigated the use of information by Ghana's members of parliament (MPs) in their decision-making process. The purpose of the study was to understand how MPs search for and locate information, how that leads to their decision-making, and what the issues involved in this process are. The authors adopted a quantitative approach and employed a questionnaire as their main instrument. 
Wilson's global model of information behavior was used as the conceptual framework to study the information behavior, needs, and use of information by MPs in Ghana. The model was also used to understand how problems encountered by the MPs when they used and searched for information affected their decision-making processes. The findings of the study revealed that MPs' information needs are directly related to their job and the responsibility they have as creators of new bills. The findings also showed that the type of information MPs used affected the outcome of their work in debates and their voting for bills.

Furthermore, Mostert and Ocholla (2005) examined the information needs and information seeking behavior of parliamentarians in South Africa. The research aimed at understanding what the information sources, services, and systems used by the South African MPs were. The research also investigated the role of the parliament libraries for the South African MPs. The authors used a quantitative approach and employed a questionnaire as their main instrument. The authors adopted Wilson's general model of information seeking behavior, which they extended into a new model as shown in Figure 1, explaining information seeking strategies popular among parliamentarians in South Africa. The results of the study showed that both the parliament libraries and other sources from the Internet were used by the MPs equally. The authors indicated that the electronic sources of information were used on a large scale, almost at the same level as printed sources. Finally, the parliament library is not well used by the MPs because of the bad marketing by the library.

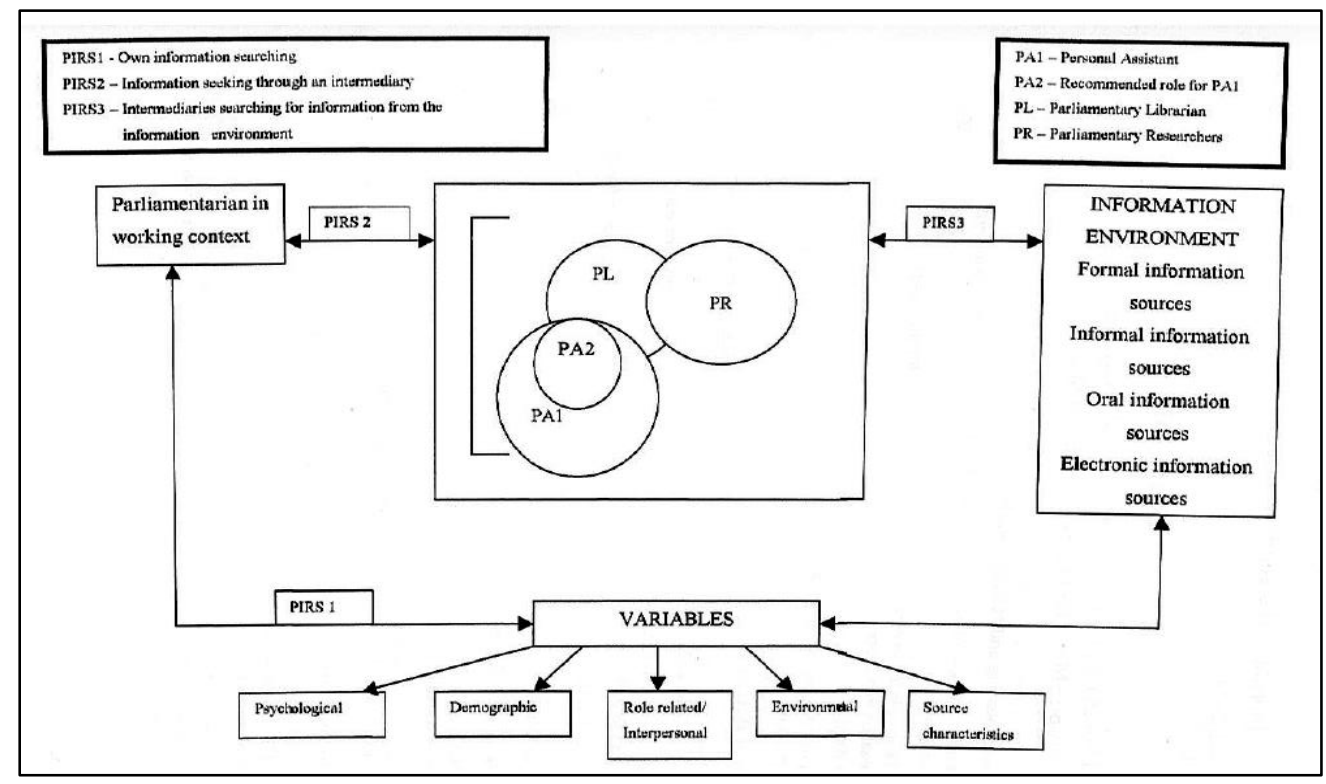

Figure 1. Information seeking behavior of parliamentarians (Mostert \& Ocholla, 2005) 
Marcella, Baxter, and Moore (2002) conducted a review of studies on the information needs related to the communication of parliamentary information. The authors stated that many researchers had noticed the shortage of models and frameworks in information seeking. The authors indicated that the problem might not be the lack of theory, but rather the lack of a road map guiding us to use or create a theory. Other studies have investigated the information seeking of the legislators all around the world. Abdullah and Hussain (2012) investigated the information needs and information use of Malaysia's members of parliament. The objective of the study was to identify the information needs of Malaysia's MPs, to recognize the sources of information and the extent of the MPs' use of those sources, and to identify the MPs' preferred channels of information. A questionnaire was delivered to 200 individuals including MPs, senators, political secretaries, and special officers. A total of 60 responses were received, a response rate of $30 \%$. The authors concluded that the findings suggested new strategies were needed by the parliament library to better serve the MPs and ensure they had convenient access to quality information, which would eventually help their decision-making.

Thapisa (1996) conducted a study on the legislative information needs of MPs in Botswana. The study focused on five main themes: the parliamentarians' perception of information, sources of information, information seeking behavior, an assessment of the National Assembly library, and an assessment of research needs. The author found that MPs demonstrated an awareness of the value and importance of information in legislative debates. The study also indicated that the MPs seek information mostly from government departments, personal contacts, and fellow Parliamentarians.

\section{Role of Information Centers/Parliament Libraries}

Information centers/parliament libraries have a great role in the decision-making process of legislators. Library centers provide legislators with essential information that covers all topics addressed by legislators. They provide professional assistance in finding desired information. Shailendra and Prakash (2007) examined the information needs of Members of the Legislative Assembly (MLAs) of Delhi, India. In their study, the library was defined as an information center, providing a variety of services such as bibliographic services, references services, and research. The authors noted that most parliamentarians were aware only of the traditional services such as the reference service. They were not aware of services such as the current awareness services, which provides them with the latest information and sources update and the online information system service. Interviewing the members of the Indian parliament, the authors found that the members were using few of the services. They gave the following reasons: lack of 
library orientation programs, poor information in the library, bad representation of services in the library, and the busy schedule of their work.

Bannenberg (1994) presented a paper on building members' understanding and support for the parliamentary information search process. He concluded that members would give greater support to the Australian Parliament Library if they had a better understanding of it and the services being offered. Members of the parliament have an almost unlimited desire for information; everything they work for depends on having the right information at the right time. MPs do not mind who fulfills this need, as long as they can reach their goal successfully. The author also suggested strategies to promote the importance of the library and its services by providing several orientation programs on the library services and seminars on topics of current interest.

Alemna and Skouby (2000) investigated the information seeking behavior of members of Ghana's legislature. A questionnaire was administered targeting all of Ghana's MPs. The sample was expected to cover all 200 MPs. However, the questionnaire was distributed to 164 participants, and 94 completed the questionnaire. The objective of the study was to explore the MPs' information needs, the degree of assistance MPs required in securing information, and the adequacy of the parliament library. The results indicated that $81 \%$ of the members were aware of the services offered by their parliament library. However, $68 \%$ were not satisfied with services provided by the library. When asked if they used or visited other libraries for their work, only $41 \%$ said that they did use other libraries.

Watt (2009) conducted a study on the changing visions of the European Parliament library. He explained that the role of the parliament library is based on the assumption that the library serves a curious and well-informed member who uses reason and science to hold the executive body to account and to contribute to their legislative work. However, it seems that this assumption is false. Information had increased continuously, and the formats and channels have changed. It had grown in scale and in scope, covering many more issues, in which legislative choices have become more complex. Now, the library faces new external trends over which they have little control. Therefore, Watt suggested the library must apply new marketing methods like business-to-business or advertising. With this method, the future development of services can be more effective and meet the information needs of the MPs in a way that is more efficient.

Mostert (2007) conducted a study regarding parliament library services in South Africa. The aim of the study was to explore the library's services and to trace its development, organization, and future plans. A survey and an observation method were used in the study. The survey was sent to ten libraries, and all ten libraries responded. The author discussed the role of the parliament library as the provider of information sources in the service of very specific clients, such as 
individual parliamentarians, parliament committees and associations, and parliament staff. He found that MPs should learn how to request information and libraries should receive these requests and prepare information on popular topics or issues under discussion during parliamentarian sessions. The author suggested that it is important to have qualified and knowledgeable library staff to efficiently serve the library users.

Members of the parliament need information all the time to fulfill their objectives as decision makers. The information they need can come from different sources, be digital or print, and be informal or formal. The information centers located in the Parliament/House of Commons are responsible to provide the necessary information to the legislators. Kimbunga (1996) argued that in order to make correct analyses and useful contributions to debates undertaken in parliament, members of the parliament need the right information at the right time. Therefore, the promptness and accuracy of information are very important to their legislative work. He mentioned that information presented to the MPs could be important knowledge extracted from both print and electronic resources and presented to them in the form of the original document, a summary or citation, or research.

Marcella, Baxter, Davies, and Toornstra (2007) found that the MPs used a wide range of information sources, including the Internet, particularly the Google search engine, through intermediaries such as committees and information services such as the parliament documentation center. Most of the MPs chose the Internet services rather than a specialized site such as the council site. The authors indicated that the MPs fell into two groups with regard to their information seeking skills: those who never performed a search or rarely performed their own search and those who infrequently used assistance from their secretaries and outside specialists. The MPs reported that they almost never used the parliamentary information services and would rather use other external services.

\section{Impact of Information Technologies}

New technology provides advantages for the legislators, including remote access, flexibility, and speed of handling information. An effective legislature will depend on reliable and efficient information obtained through its own channels. This will provide an effective and efficient information system to support decision-making by the legislators.

The Parliamentary On-line Information System (POLIS) is a good example of an effective legislative information system. POLIS was designed specially to handle the urgent information needs of members of the parliament of the British House of Commons. POLIS is a database of all legislative work as well as all library holdings and other legislative documents. In an earlier study 
conducted on the U.K. parliament, Serema (1999) described the importance of information technology and showed there was a growing range of information technologies used by the MPs. For example, the parliamentary data and video network (PDVN) helped the MPs, their staff, and the House of Commons to communicate with each other and to connect simultaneously to a variety of kinds of information. The PDVN provides services such as electronic mail and access to the World Wide Web.

Chappelet (2004) examined the use of information and communication technologies by MPs in Switzerland. The study data collection tool was based on an Internet questionnaire that included areas such as the MPs' use of and opinions about the use of the Internet and e-mail in their political and civilian lives. The study revealed that more than half of the MPs $62.5 \%$ used the Internet daily. Most the MPs $85.2 \%$ agreed that the Internet was informative for them.

Watt (2010) studied the changing visions of the parliament libraries. The author questioned the role of the library in providing the necessary information to help the MPs with their decision-making. He argued that the idea that the library is necessary is becoming a myth. The author argues that since 1990, web-based services have been used more and more by the MPs and that books are being neglected. The author argued that in the modern world traditional library services are no longer efficient for the decision-making process. Parliament libraries must provide new services to connect the MPs to new technologies. The author suggested that MPs must benefit from social media tools (e.g., Facebook) to connect with the citizens in order to be more effective in their decision-making.

The use of social media such as Facebook, Twitter, and Instagram by legislators has been growing in recent years. Legislators have begun to realize how efficient social media is for locating and gathering information. Some legislators use social media to gather information rather than using the traditional sources. Missingham (2011) conducted a study on the Parliamentary library and research services in the 21 st century. The study discussed changes related to the emergence of a digital presence that have appeared in many countries around the world. The main objective for the members was to be supported in the virtual environment wherever they were through a variety of channels, including mobile devices and computers, to communicate with the wider world and to get information that they required from the parliament, particularly in media format through the parliamentary web site. The author pointed out that the use of social media and Web 2.0 technology has emerged over the past few years as the hottest growing area for online communication and perhaps communication in general. Furthermore, social media provided many ways to access information, which has evolved into greater expectations of interaction and engagement in legislative development. In conclusion, technology will increasingly grow, and it will affect the way MPs seek and retrieve information. 
Wandhoefer, Thamm, and Joshi (2011) investigated information behavior and dissemination on social network sites. The authors tried to understand the reason behind using SNSs, specifically Facebook, by German parliament members and how they implement it in their workflow. The study conducted 16 semi-structured interviews. The authors found that all the participants tended to use Facebook and Twitter. The result of the study indicated that the parliament members used SNSs as a tool to engage with the public. Moreover, using SNSs not only helps the parliamentarians to increase their popularity but also helps them in their decision-making.

Perhaps the most used social media tool for legislative work is Twitter. Many studies have investigated the use of Twitter by legislators. Golbeck, Grimes, and Rogers (2010) conducted a study on the use of Twitter by the United State of America Congress. A content analysis was carried out on over 6000 Tweets sent by the all the congress members' Twitter accounts. The purpose of the study was to understand and to analyze the type of content posted in the members of the congress' Twitter accounts. The results of the study indicated that most the members of congress tended to use Twitter to post about their achievements, activities, and location rather than using it to communicate with the public. Another study with similar results by Jackson and Lilleker (2011) investigated the United Kingdom members of parliament's Twitter use. The authors analyzed the Twitter accounts of the members of the parliament, and the results indicated that that majority of the members used their accounts to promote their personal activities. However, only a minority of the members used their Twitter accounts to interact with and reach the public.

\section{Research Horizons}

As discussed above, the concept of information seeking dates to before WWII, but the rise of the information seeking area began after WWII, and the most significant development was the two information conferences in 1948 and 1958. Soon after, many scholars noticed the increased interest in information seeking studies in the field of library and information science and other disciplines. Furthermore, technology also played a major role in information seeking for both the researchers and the research participants. There are a variety of terms designating the field, but some scholars identify information behavior as the most used term. Over the years many theories and models, such as Ellis' information seeking, Bates' berrypicking, and Wilson's information behavior, have been created. Moreover, there have been several studies in other countries all over the world about the information seeking behavior of legislators. Many of the studies tend to focus on the legislators' point of view, their information needs and the ways in which the information retrieved by the legislators has an impact on their 
decision-making process and on the whole society. Most of the studies come from the library and information science discipline, and only few come from the political science discipline. My research seeks to contribute to this literature.

Currently, I am gathering quantitative and qualitative data to examine the information seeking behavior of the Kuwait National Assembly (KNA) in light of Wilson's model as interpreted by Mostert and Ocholla (2005). As we see in many institutions around the world, we see in Kuwait that the rapid rise in the use of various sources such as social media creates an unfamiliar information environment; we see changes in who can ask what kinds of questions; we see changes in who speaks with whom; we see new ways of managing old forms of social engagement. New media do not, in and of themselves, generate better conditions, though they may well do that (O'Connor, Kearns, \& Anderson, 2008). Modeling the information environment of the KNA will provide insights into information seeking behavior in an era of unparalleled spread of digital media.

During the process of collecting information, if the KNA members obtain unreliable information or act without using the best information available, it may result in the making of inappropriate decisions. Therefore, there is a need to investigate the information behavior of the KNA members in collecting information for their legislative work and the impact of technology - specifically social media and information centers - on their decision-making process. The study will provide suggestions that will help to improve the services and resources to enhance the utilization of the information center. This study will also help to identify the gaps and set a clear map on how to obtain and use necessary information for their legislative work. Finally, it may also help by providing reliable bills by legislators that reflect actual need of their society.

\section{References}

Abdullah, S. \& Hussain, H. (2012). The information need and information use of Malaysia's members of parliament. Paper presented at the 78th IFLA General Conference, Helsinki, Finland.

Alemna, A. A., \& Skouby, K. E. (2000). An investigation into the information needs and information-seeking behavior of members of Ghana's Legislature. Library Management, 21(5), 235-240.

Bannenberg, N. (1994). Building member understanding and support for the parliamentary. Paper presented at the 60th IFLA General Conference, Queensland, Australia.

Bates, M. J. (1999). The invisible substrate of information science. Journal of the Association for Information Science and Technology, 50(12), 1043. 
Bates, M. J. (2010). Information behavior. In M. Bates \& M. N. Maack (Eds.), Encyclopedia of library and information sciences, third edition (pp. 23812391). New York, NY: Taylor \& Francis.

Camp, W. (2001). Formulating and evaluating theoretical frameworks for career and technical education research. Journal of Vocational Education Research, 26(1), 4-25.

Case, D. O. (2012). Looking for information: A survey of research on information seeking, needs, and behavior (3rd ed.). Bingley, UK: Emerald.

Chappelet, J. L. (2004). The appropriation of e-mail and the Internet by members of the Swiss Parliament. The International Journal of Government \& Democracy in the Information Age, 9(2), 89-102.

Folster, M. B. (1995). Information seeking patterns: Social sciences. The Reference Librarian, 23(49-50), 83-93.

Frankor, D. K., \& Akussah, H. (2012). Information use and policy decisionmaking by district assembly members in Ghana. Information Development, 28(1), 32-42.

Golbeck, J., Grimes, J. M., \& Rogers, A. (2010). Twitter use by the US Congress. Journal of the American Society for Information Science and Technology, 61(8), 1612-1621.

Jackson, N., \& Lilleker, D. (2011). Microblogging, constituency service and impression management: UK MPs and the use of Twitter. The Journal of Legislative Studies, 17(1), 86-105.

Kimbunga, M. K. (1996). The role of parliamentary library and research services in multi-party Tanzania. Library Review, 45(6), 18-24.

Kuhlthau, C. C. (2004). Seeking meaning: A process approach to library and information services (2nd ed.). Santa Barbara, CA: Libraries Unlimited.

Marcella, R., Baxter, G., \& Moore, N. (2002). Theoretical and methodological approaches to the study of information need in the context of the impact of new information and communications technologies on the communication of parliamentary information. Journal of Documentation, 58(2), 185-210.

Marcella, R., Baxter, G., Davies, S., \& Toornstra, D. (2007). The information needs and information seeking behavior of the users of the European parliamentary documentation center: A customer knowledge study. Journal of Documentation, 63(6), 920-934.

Marcella, R., Carcary, I., \& Baxter, G. (1999). The information needs of United

Kingdom members of the European Parliament (MEPs). Library

Management, 20(3), 168-178.

Marchionini, G. (1997). Information seeking in electronic environments. Cambridge, UK: Cambridge University Press.

Missingham, R. (2011). Parliamentary library and research services in the 21st century: A Delphi study. IFLA Journal, 37(1), 52-61. 
Mostert, B. J. (2007). Parliamentary library services in South Africa. South African Journal of Libraries and Information Science, 73(2), 156-167.

Mostert, B. J., \& Ocholla D. N. (2005). Information needs and information seeking behavior of parliamentarians in South Africa. South African Journal of Libraries and Information Science, 71(2), 136-150.

O'Connor, B. C., Kearns, J., \& Anderson, R. L. (2008). Doing things with information: Beyond indexing and abstracting. Westport, CT: Libraries Unlimited.

Ocholla, D. N. (1999). Insights into information-seeking and communicating behavior of academics. International Information \& Library Review, 31(3), 111-143.

Orton, R., Marcella, R., \& Baxter, G. (2000). An observational study of the information seeking behavior of members of parliament in the United Kingdom. Aslib Proceedings, 52(6), 207-217.

Osman, H., \& Agyei, D. D. (2014) Information use in decision-making by parliamentarians in Ghana. Library Philosophy and Practice. Retrieved from

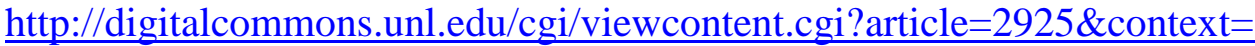
libphilprac

Rocco, T. S., \& Hatcher, T. (2011). The handbook of scholarly writing and publishing. San Francisco, CA: John Wiley \& Sons.

Saracevic, T. (1999). Information science. Journal of the American Society for Information Science, 50(12), 1051-1063.

Serema, B. C. (1999). Matching MPs information needs and information services in the House of Commons. Library Management, 20(3), 179-190.

Shailendra, K., \& Prakash, H. (2007). A study of information needs of members of the Legislative Assembly in the capital city of India. Aslib Proceedings, 60(2), 158-179.

Thapisa, A. P. N. (1996). Legislative information needs of indigenous parliamentarians in Botswana and impact on effective decision-making. The International Information \& Library Review, 28(3), 203-232.

Wandhoefer, T., Thamm, M., \& Joshi, S. (2011). Politician 2.0: Information behavior and dissemination on social networking sites gaps and bestpractices. eJournal of eDemocracy \& Open Government, 3(2), 207-215.

Watt, I. (2009). Changing visions of parliamentary libraries. Paper presented at the 75th IFLA General Conference and Council, Milan, Italy.

Watt, I. (2010). Changing visions of parliamentary libraries: From the enlightenment to Facebook. IFLA Journal, 36(1), 47-60.

Wilson, T. D. (1981). On user studies and information needs. Journal of Documentation, 37(1), 3-15. 
Wilson, T. D. (1997). Information behavior: An interdisciplinary perspective. Information Processing \& Management, 33(4), 551-572.

Wilson, T. D. (1999). Models in information behavior research. Journal of Documentation, 55(3), 249-270.

Wilson, T. D. (2000). Human information behavior. Informing Science, 3(2), 4956.

Wilson, T. D. (2006). On user studies and information needs. Journal of Documentation, 62(6), 658-670.

Wilson, T. D. (2009). Fifty years of information behavior research. Bulletin of the American Society for Information Science \& Technology, 36(3), 27-34. 